\title{
Radiographic prevalence of root canal ramifications in a sample of root canal treatments in a Brazilian Dental School
}

\author{
Prevalência radiográfica de ramificações \\ do canal radicular em uma amostra de \\ tratamentos endodônticos em uma Faculdade \\ de Odontologia Brasileira
}

\begin{abstract}
ladasa de Quadros(a)
Alexandre Augusto Zaia(b)

Caio Cezar Randi Ferraz(b)

Francisco José de Souza Filho(b)

Brenda Paula Figueiredo de Almeida Gomes $^{(b)}$
\end{abstract}

(a) MSc in Endodontics; (b) Associate Professors of Endodontics - School of Dentistry of Piracicaba, State University of Campinas.

\section{Corresponding author:}

Brenda Paula Figueiredo de Almeida Gomes Faculdade de Odontologia de Piracicaba FOP/UNICAMP

Departamento de Endodontia

Av. Limeira, 901 - Piracicaba - SP - Brazil

CEP: 13414-900

E-mail:bpgomes@fop.unicamp.br

Received for publication on Jun 05, 2006 Sent for alterations on Aug 02, 2006 Accepted for publication on Oct 03, 2006
Abstract: The aim of this study was to radiographically investigate the presence of root canal ramifications found after endodontic treatment, and to determine any relationship between their presence and the type of the auxiliary chemical substance used. The study evaluated 1,470 endodontic treatments performed by final year undergraduate students at the Dental School of Piracicaba, State University of Campinas (UNICAMP), SP, Brazil, during the period from 1998 to 2000. The X-rays taken during treatment were evaluated in order to establish the presence of ramifications of the root canal system. The initial X-ray did not show the presence of any canal ramifications. After filling, X-rays showed only 3 ramification types: $3.06 \%$ of lateral canals, $2.99 \%$ of apical deltas, and $0.1 \%$ of interradicular canals. The maxillary premolars showed the highest number of lateral canals $(\mathrm{n}=13)$, followed by mandibular premolars $(\mathrm{n}=10)$ and maxillary incisors $(\mathrm{n}=10)$. Apical deltas were mostly found in mandibular molars $(n=14)$, followed by maxillary incisors $(n=9)$. Only mandibular molars had interradicular canals. The detection of ramifications increased with the use of EDTA. However, no statistically significant relationship was found between the type of auxiliary chemical substance used and the number of root canal ramifications detected after root canal filling. It was concluded that the frequency of root canal ramifications found radiographically was low in treatments performed by undergraduate students.

Descriptors: Endodontics; Root canal; Dental records; Education, dental.

Resumo: O objetivo deste estudo foi investigar radiograficamente a presença de ramificações do canal radicular encontrada depois do tratamento endodôntico, e determinar qualquer relação entre a presença destas e do tipo de substância química auxiliar usada. O estudo avaliou 1.470 tratamentos endodônticos executados pelos estudantes do último ano da Faculdade de Odontologia de Piracicaba, Universidade Estadual de Campinas (UNICAMP), SP, Brasil, no período de 1998 a 2000. Foram avaliadas as radiografias feitas durante o tratamento para verificar a presença das ramificações dos sistemas de canais radiculares. A radiografia inicial não mostrou a presença de qualquer ramificação. Depois da obturação as radiografias mostraram apenas 3 tipos de ramificação: 3,06\% de canais laterais, $2,99 \%$ de deltas apicais e $0,1 \%$ de canais interradiculares. Os pré-molares superiores mostraram o maior número de canais laterais $(n=13)$, seguidos pelos pré-molares inferiores $(n=10)$ e incisivos superiores $(n=10)$. Deltas apicais foram encontrados principalmente em molares inferiores $(n=14)$, seguidos por incisivos superiores $(n=9)$. Apenas molares inferiores apresentaram canais interradiculares. A detecção de ramificações aumentou com o uso do EDTA. Entretanto, nenhuma relação estatisticamente significante foi encontrada entre o tipo de substância química auxiliar usada e o número de ramificações visualizadas após a obturação dos canais radiculares. Foi concluído que a freqüência de ramificações do canal radicular encontrada radiograficamente é baixa em tratamentos executados por estudantes universitários.

Descritores: Endodontia; Canal radicular; Registros odontológicos; Educação em odontologia. 


\section{Introduction}

The main objective of endodontic therapy is to promote the chemo-mechanical cleansing of the entire pulp cavity and to perform its complete obturation with an inert filling material. The chemomechanical preparation plays an important role in removing pulpal (organic) and dentinal debris (inorganic), as well as microorganisms from the root canal system. The preparation is mechanically performed using endodontic files and thoroughly irrigating the canal with an inert solution in order to remove debris. In addition, the canal must be chemically prepared using an auxiliary chemical substance or a combination of substances. ${ }^{9}$ It is also well known that smear layer removal provides effective decontamination and improves the seal of root fillings, as the sealer penetrates into the open dentinal tubules, which decreases microleakage. ${ }^{2,18}$

The obturation of the entire root canal system, from crown to apex, is meant to eliminate empty spaces and to preserve the decontamination performed in the course of the chemo-mechanical cleansing step. ${ }^{11}$

Although it has been reported that non-microbial factors might be implicated in root canal treatment failure, the literature suggests that persistent interradicular or secondary infections are the major causes of failure of root canal treatment. ${ }^{17}$ Moreover, persistence of microorganisms is more related to the anatomical complexity of root canals than to operator inadequacies. ${ }^{7}$ An inadequate chemo-mechanical preparation and root canal filling associated with untreated and unfilled canal ramification and isthmus contribute to the persistence of infection and, consequently, failure of the root canal treatment.

A canal is often left untreated because the dentist fails to recognize its presence. The dentist must have a thorough knowledge of root canal morphology before being able to successfully perform endodontic treatment. ${ }^{13,20}$

Root-canal morphology studies have used freshly extracted teeth and clearing techniques. ${ }^{5,10}$ Previous studies have suggested that radiographic images are not reliable for the detection of multiple canals and lateral canals, and could not distinguish centrally placed apical foramina from those eccentrically located. The clearing technique, which makes the teeth somewhat transparent, has considerable value in studying the anatomy of the root-canal system. This is because, unlike radiographic images, it provides a three-dimensional view of the pulp cavity in relation to the exterior of the tooth and allows a thorough examination of pulp chambers and root canals. However, the clearing technique remains useful only as a teaching/research tool with little or no clinical applicability.

Furthermore, transverse anastomosis in molars, lateral canals and apex deltas are important communication pathways between the pulp and the periodontium. In their studies, Rubach, Mitchell ${ }^{15}$ (1965); Bender, Seltzer ${ }^{3}$ (1972); Ross ${ }^{14}$ (1972) and Gutmann $^{8}$ (1978) indicated that toxins and inflammatory products can pass between these two structures through the lateral, accessory and apex canals.

Vertucci ${ }^{20}$ (1984), using the clearing technique, made a detailed study of two thousand and four hundred permanent teeth. The results showed great variation in root canal anatomy. The most variable root canal anatomy was found among maxillary second premolars. The rate of lateral canals in maxillary molars was around $50 \%$ in the mesiobuccal roots, and they were mostly found at the apex. In the mandibular molars (mainly first molar), lateral canals were found in great numbers in the furcation region.

The aim of this study was to radiographically investigate the presence of root canal ramifications found after endodontic treatment was performed by final year undergraduate students and to determine any relationship between their visualization and the type of auxiliary chemical substance used.

\section{Material and Methods}

This study evaluated 1,470 teeth whose endodontic treatment was performed by final year undergraduate students at the Dental School of Piracicaba, State University of Campinas, SP, Brazil, during the period from 1998 to 2000 . The research was approved by the Human Volunteers Research and Ethics Committee, Dental School of Piracicaba. 
All treatments were done with rubber dam after asepsis. The instrumentation proceedings were done employing the hybrid technique according to Valdrighi et al. ${ }^{19}$ (1991). The coronal two-thirds of each canal were prepared initially using files up to size 35. A size 2 Gates-Glidden bur (GG) (Dentsply-Maillefer Co., Ballaigues, Switzerland) was then used with gentle force up to the length of the coronal two-thirds of the canal followed by a size 3 GG bur up to a length $1 \mathrm{~mm}$ shorter than the previous one. A size 10 file (Dentsply-Maillefer Co., Ballaigues, Switzerland) was used to run through the canal $1 \mathrm{~mm}$ beyond the length of the coronal two-thirds between each file and bur, in order to maintain the passage of canal patency. A size 15 K-file (Dentsply Maillefer, Ballaigues, Switzerland) with rubber stop was introduced carefully into each canal in order to determine the work length. Apical instrumentation commenced with a straight file of the same size as the apical foramen and the canal was enlarged up to 3 file sizes larger. The instrument was used with a half turn reaming action until the file became loose within the canal. The canal was instrumented with an increasing succession of files until the master apical file was reached. The root canals were further instrumented following a step-back enlargement with $1 \mathrm{~mm}$ increments up to three sizes larger than the master apical file. The master file used to prepare the apical stop and a size 10 file was used to maintain the foramen patency.

The available auxiliary chemical substances were $0.5 \%$ and $1 \% \mathrm{NaOCl} ; 17 \%$ EDTA or $2 \%$ chlorhexidine (CHX) gel. The $\mathrm{NaOCl}$ and EDTA were prepared in the same drugstore (Proderma Farmácia de manipulação LTDA., Piracicaba, SP, Brazil). The EDTA was used before placement of intracanal medication or root filling. It was removed with a final flush with $0.89 \%$ sterile saline solution. The chlorhexidine gel (Endogel $^{\mathrm{TM}}$, Endosupport, Itapetininga, SP, Brazil) consisted of a water-soluble gel base ( $1 \%$ natrosol) and $\mathrm{CHX}$ gluconate.

The root canals were filled using standardized gutta-percha points (Tanariman, Manaus, AM, Brazil) and a zinc oxide sealer (Endométhasone, Septodont, Ain-Maur, France) during the lateral condensation technique. Excess gutta-percha was seared off with a hot instrument (Paiva's plugger, Dentsply Indústria e Comércio Ltda., Petrópolis, RJ, Brazil). The cervical portion of the warm guttapercha was vertically condensed by firmly using a Paiva's plugger \# 2. A layer of Coltosol was placed into the canal orifices after removing $2 \mathrm{~mm}$ of guttapercha and sealer from the entrance of the canal. ${ }^{24}$ If the involved tooth would not receive a prosthetic restoration, a permanent restoration was placed at the end of the root canal treatment, or at least one week after the procedure. If it was known that there would be delay in the prosthetic restoration, a $2 \mathrm{~mm}$ thick Coltosol seal was performed followed by the placement of resin.

All the X-rays taken during the treatment were studied in order to check the frequency and to classify the ramifications of the root canal system. The radiographs were examined using an $\mathrm{X}$-ray viewer and magnifying lens (X 3).

The canal ramifications after root canal fillings were classified as: lateral canals, apical deltas and interradicular canals.

All the clinical records and the types of root canal ramification found before and after the root canal filling procedure were entered into a computerized database. The Pearson chi-square test or the one-sided Fisher's Exact test, as appropriate, were chosen to test the null hypothesis that there was no relationship between the presence of root canal ramification and the use of auxiliary chemical substance, in the clinical records evaluated.

\section{Results}

The initial X-ray, taken with the parallel technique, did not show the presence of any root canal ramifications.

Table 1 shows the frequency of each teeth group with endodontic treatment. In the 3-year study, the most treated tooth was the mandibular molar.

After the filling of the canals, X-ray evaluations showed 3 ramifications types: $3.06 \%$ of lateral canals $(n=45 / 1,470) ; 2.99 \%$ of apical deltas ( $n=44 / 1,470)$; and $0.1 \%$ of interradicular canals $(2 / 1,470)$. The highest incidences of lateral canals $(2.9 \%, \mathrm{n}=17)$ and apical deltas $(3.10 \%, \mathrm{n}=18)$ occurred in teeth treated in 2000. Interradicular ca- 
nals were found in $1998(0.32 \%, \mathrm{n}=1)$ and in 1999 $(0.17 \%, \mathrm{n}=1)$ (Graph 1).

The maxillary premolars showed the highest rate of lateral canals $(0.88 \%, \mathrm{n}=13)$; followed by mandibular premolars $(0.68 \%, \mathrm{n}=10)$ and maxillary

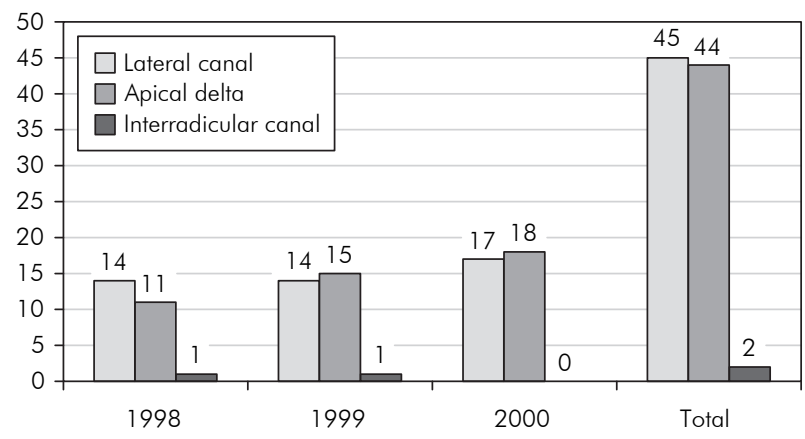

Graph 1 - Total number of ramification types in each period. incisors $(0.68 \%, \mathrm{n}=10)$. Apical deltas were mostly found in mandibular molars $(0.95 \%, \mathrm{n}=14)$, followed by maxillary incisors $(\mathrm{n}=9)$. Only the mandibular molar group presented interradicular canals (Graph 2).

During 1998, the mostly used auxiliary chemical substance was $0.5 \% \mathrm{NaOCl}$. In 1999 , some of the canals were irrigated with $1 \% \mathrm{NaOCl}$ and, in some of the cases, $17 \%$ EDTA was used as a final auxiliary chemical substance. In 2000, some cases were irrigated with $2 \%$ chlorhexidine gel. The use of EDTA (after using the auxiliary chemical substance) increased in 2000, as shown in Table 2, as well as the detection of root canal ramifications in the same period (Graph 1). However, no statistically significant relationship was found between the type of auxiliary chemical substance used and the number of root canal ramifications detected after root canal filling $(p>0.05)$.

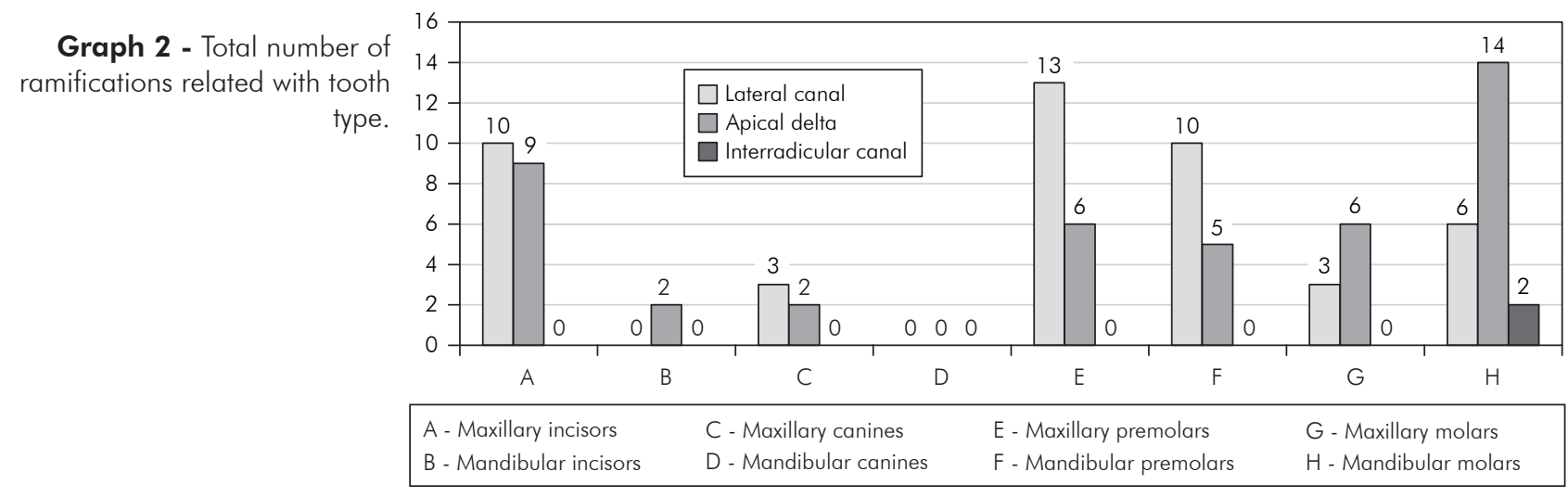

Table 1 - Total number of tooth types treated in each year.

\begin{tabular}{l|c|c|c|c|r|r|r|r}
\hline \multirow{2}{*}{} & \multicolumn{2}{|c|}{1998} & \multicolumn{2}{c|}{1999} & \multicolumn{2}{c}{2000} & \multicolumn{2}{c}{ Total } \\
\cline { 2 - 10 } & $\mathrm{n}$ & $(\%)$ & $\mathrm{n}$ & $(\%)$ & $\mathrm{n}$ & \multicolumn{1}{c}{$(\%)$} & $\mathrm{n}$ & $(\%)$ \\
\hline Maxillary incisor & 69 & $(22.4)$ & 136 & $(23.3)$ & 132 & $(22.7)$ & 337 & $(22.9)$ \\
\hline Maxillary canine & 30 & $(9.7)$ & 36 & $(6.1)$ & 32 & $(5.5)$ & 98 & $(6.6)$ \\
\hline Maxillary premolar & 52 & $(16.8)$ & 93 & $(15.9)$ & 93 & $(16.0)$ & 238 & $(16.1)$ \\
\hline Maxillary molar & 46 & $(14.9)$ & 66 & $(11.3)$ & 70 & $(12.0)$ & 182 & $(12.4)$ \\
\hline Mandibular incisor & 6 & $(1.9)$ & 26 & $(4.4)$ & 18 & $(3.1)$ & 50 & $(3.4)$ \\
\hline Mandibular canine & 3 & $(0.9)$ & 23 & $(3.9)$ & 22 & $(3.7)$ & 48 & $(3.2)$ \\
\hline Mandibular premolar & 28 & $(9.0)$ & 64 & $(10.9)$ & 79 & $(13.6)$ & 171 & $(11.6)$ \\
\hline Mandibular molar & 74 & $(24.0)$ & 139 & $(23.8)$ & 133 & $(22.9)$ & 346 & $(23.5)$ \\
\hline Total & 308 & $(21.0)$ & 583 & $(39.6)$ & 579 & $(39.4)$ & 1470 & $(100.0)$ \\
\hline
\end{tabular}


Table 2 - Auxiliary chemical substance distribution related with treatment number in each studied year.

\begin{tabular}{l|c|c|c|c}
\hline \multirow{2}{*}{$\begin{array}{c}\text { Auxiliary } \\
\text { chemical } \\
\text { substance }\end{array}$} & 1998 & 1999 & 2000 & Total \\
\cline { 2 - 6 } & $\mathrm{n}(\%)$ & $\mathrm{n}(\%)$ & $\mathrm{n}(\%)$ & $\mathrm{n}(\%)$ \\
\hline $0.5 \% \mathrm{NaOCl}$ & $302(98.1)$ & $511(87.7)$ & 0 & $813(55.3)$ \\
\hline $1 \% \mathrm{NaOCl}$ & 0 & $69(11.8)$ & $505(87.2)$ & $574(39)$ \\
\hline $17 \% \mathrm{EDTA}$ & $10(3.2)$ & $47(8.1)$ & $340(58.7)$ & $397(27)$ \\
\hline $2.0 \mathrm{CHX}$ gel & 0 & 0 & $33(5.7)$ & $33 \quad(2.2)$ \\
\hline
\end{tabular}

\section{Discussion}

Conventional radiography can render only a twodimensional image, and therefore does not allow a three-dimensional study of the root canal system and its ramifications. However, the X-ray is the only clinical method to investigate root canal ramifications. Unfortunately, most of the time we can detect the existence of root canal ramifications only after filling, or when there is a previous image of a periradicular radiolucency, which can suggest a communication between the main canal and the periodontal ligament. Due to the radiographic superimposition, the small dimension of these canals and the limitations of radiographs, in most cases, these ramifications cannot be observed.?

Filling of the teeth was done by lateral condensation with gutta-percha, using Endométhasone as sealer in all cases. The number of ramifications clinically found after obturation (final X-ray) $(6.19 \%, n=91 / 1,470)$ was lower than that found in an in vitro study of root canal systems $(27.45 \%$, $\mathrm{n}=313 / 1,140) .{ }^{6}$ It should be noted that in vitro studies have evaluated the three-dimensional picture of cleared teeth, whereas in vivo studies employ a radiographic technique.

Vertucci's classification considers as a lateral canal all canals that connect the main canal with the periodontal ligament, independently of root localization. ${ }^{20}$ In the present study, the following ramification types were found: lateral canal, apical delta and interradicular canal. Premolars were the tooth type which showed the highest number of lateral canals, and molars, the highest number of apical deltas. This proportion agrees with that of a previous study. ${ }^{6}$

$\mathrm{NaOCl}$ followed by $17 \%$ EDTA was used to re- move the smear layer. When it is present, the smear layer interferes with the diffusion of antimicrobial agents used during the chemo-mechanical preparation. ${ }^{1,4,21}$ Moreover, it also interferes with the sealer penetration into the dentinal tubules, consequently interfering with the bonding. ${ }^{22,23}$ Smear layer degradation by proteolytic bacteria enzymes leads to the formation of hollow spaces between the root canal filling material and the root canal wall, which might allow microleakage. ${ }^{12,16}$

In the present work, the detection of root canal ramifications increased from 1998 to 2000, as did the use of a substance for smear layer removal (EDTA) during the same period. Since the introduction of $1 \% \mathrm{NaOCl}(1999)$ and $2 \%$ chlorhexidine gel (2000) as auxiliary chemical substances in undergraduation clinics, the use of EDTA has strongly been emphasized. However, no statistically significant association was found between type of auxiliary chemical substance and frequency of root canal ramification. It is important to note that the number of canals irrigated with EDTA could be greater than that stated in the clinical records, since students are orientated to use it before intracanal medication and root canal filling. Unfortunately, many of the students' treatment records $(\mathrm{n}=50)$ did not state the auxiliary chemical substance used. For this reason, the total number of cases presented in Table 2 ( $n=1,420)$, without counting the number of treatments with EDTA (as it was not used alone), was not similar to that presented in Table $1(\mathrm{n}=1,470)$.

Further clinical trials involving not only dental schools but also specialist clinics are necessary in order to obtain stronger evidence of the number of ramifications filled after root canal treatment. In such studies, other factors such as filling technique should also be evaluated for their effectiveness in filling the root canal ramifications.

\section{Conclusions}

It was concluded that the frequency of root canal ramifications radiographically found was not high in treatments performed by undergraduate students, although the clinically found number will always be expected to be smaller than that found in in vitro studies. 


\section{Acknowledgements}

The authors would like to express their sincere gratitude to Professor Harald Eriksen for valuable advice. We would also like to thank $\mathrm{Mr}$.

\section{References}

1. Baumgartner JC, Mader CL. A scanning electron microscopic evaluation of four root canal irrigation regimens. J Endod. 1987;13(4):147-57.

2. Behrend GD, Cutler CW, Gutmann JL. An in vitro study of smear-layer removal and microbial leakage along root canal fillings. Int Endod J. 1996;29(2):99-107.

3. Bender IB, Seltzer S. The effect of periodontal disease on the pulp. Oral Surg Oral Med Oral Pathol. 1972;33(3):458-77.

4. Byström A, Sundqvist G. The antibacterial action of sodium hypochlorite and EDTA in 60 cases of endodontic therapy. Int Endod J. 1985;18(1):35-40.

5. Çaliskan MK, Pehlivan Y, Sepetcioglu F, Turkun M, Tuncer SS. Root canal morphology of human teeth in a Turkish population. J Endod. 1995;21(4):200-4.

6. De Deus QD. Frequency, location, and direction of lateral secondary and accessory canals. J Endod. 1975;1(11):361-6.

7. Gomes BPFA, Rodrigues HH, Tancredo N. The use of a modelling technique to investigate the root canal morphology of mandibular incisors. Int Endod J. 1996;29(1):29-36.

8. Gutmann JL. Prevalence, location, and patency of accessory canals in the furcation region of permanent molars. J Periodontol. 1978;49(1):21-6.

9. Harrison JW. Irrigation of the root canal system. Dent Clin North Am. 1984;28(4):797-808.

10. Karagoz-Kucukay I. Root canal ramifications in mandibular incisors and efficacy of low-temperature injection thermoplasticized gutta-percha filling. J Endod. 1994;20(5):236-40.

11. Lopes HP, Siqueira JF Jr, Elias CN. Scanning electron microscopic investigation of the surface of gutta-percha cones after cutting. J Endod. 2000;26(7):418-20.

12. Meryon SD, Brook AM. Penetration of dentin by three oral bacteria in vitro and their associated cytotoxicity. Int Endod J. 1990;23(4):196-202.

13. Peikoff MD, Perry JB, Chapnick LA. Endodontic failure attributable to a complex radicular lingual groove. J Endod. 1985;11(12):573-7.
Adailton dos Santos Lima for technical support. This work was supported by the Brazilian agencies FAPESP (04/05743-2; 04/07057-9), and CNPq (304282/2003-0 \& 140113/03-7).

14. Ross IF. The relation between periodontal and pulpal disorders. J Am Dent Assoc. 1972;84(1):134-9.

15. Rubach WC, Mitchell DF. Periodontal disease, accessory canals and pulp pathosis. J Periodontol. 1965;36:34-8.

16. Sen BH, Wesselink PR, Türkün M. The smear layer: a phenomenon in root canal therapy. Int Endod J. 1996;28(3):141-8.

17. Siqueira Junior JF. Aetiology of root canal treatment failure: why well-treated teeth can fail. Int Endod J. 2001;34(1):110.

18. Taylor JK, Jeansonne BG, Lemon RR. Coronal leakage: effects of smear layer, obturation technique and sealer. J Endod. 1997;23(8):508-12.

19. Valdrighi L, Biral RR, Pupo J, Souza Filho FJ. Técnicas de instrumentação que incluem instrumentos rotatórios no preparo biomecânico dos canais radiculares. In: Leonardo MR, Leal JM, editors. Endodontia - Tratamento de canais radiculares. São Paulo: Panamericana; 1991 p. 290-9.

20. Vertucci FJ. Root canal anatomy of the human permanent teeth. Oral Surg Oral Med Oral Pathol. 1984;58(5):589-99.

21. Vivacqua-Gomes N, Gomes BPFA, Zaia AA, Teixeira FB, Souza-Filho FJ. Influence of irrigants on the coronal microleakage of laterally condensed gutta-percha root fillings. Int Endod J. 2002;35(9):791-5.

22. White RR, Goldman M, Lin PS. The influence of the smeared layer upon dentinal tubule penetration by endodontic filling materials. Part II. J Endod. 1987;13(8):369-74.

23. White RR, Goldman M, Lin PS. The influence of the smeared layer upon dentinal tubule penetration by plastic filling materials. J Endod. 1984;10(12):558-62.

24. Zaia AA, Nakagawa R, De Quadros I, Gomes BPFA, Ferraz CCR, Teixeira FB et al. An in vitro evaluation of four materials as barriers to coronal microleakage in endodontically treated teeth. Int Endod J. 2002;35(9):729-34. 